\title{
Lipoid proteinosis
}

\section{Lipoid proteinozis}

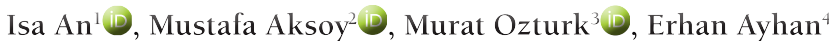 \\ ${ }^{1}$ Dept. of Dermatology, Sanliurfa Training and Research Hospital, Sanliurfa, Turkey, ${ }^{2}$ Dept. of Dermatology, Harran University Medical \\ Faculty, Sanliurfa, Turkey, ${ }^{3}$ Dept. of Dermatology, Health Sciences University, Van Training and Research Hospital, Van, Turkey, ${ }^{4}$ Dept. of \\ Dermatology, Health Sciences University, Gazi Yasargil Training and Research Hospital, Diyarbakir, Turkey
}

\begin{abstract}
Lipoid proteinosis (LP) is a rare autosomal recessive genodermatosis characterized by the accumulation of an amorphous hyaline material in various regions of the body, including skin, mucous membranes, brain, internal organs. LP is caused by mutations in the gene encoding the extracellular matrix protein 1 (ECM1) found on chromosome 1q21. Although this disease is rare, it is more reported in areas where consanguineous marriages are common. During the infancy, it begins with hoarseness due to laryngeal infiltration. Gradually, skin and mucous changes become clinically evident. The affected individuals have a normal survey unless laryngeal obstruction develops. A multidisciplinary approach is recommended for monitoring these patients.
\end{abstract}

Key words: ECM1, lipoid proteinosis, moniliform blepharosis

O̊z

Lipoid proteinozis (LP) deri, muköz membranlar, beyin, iç organlar dahil olmak üzere vücudun çeşitli bölgelerinde, amorf bir hiyalin materyalin birikmesi ile karakterize, nadir görülen otozomal resesif bir genodermatozdur. LP kromozom 1q21'de bulunan ekstraselüler matriks proteini 1 (ECM1)'i kodlayan gendeki mutasyonlardan kaynaklanır. Bu hastalık nadir görülmekle birlikte ülkemizde özellikle akraba evliliklerinin sık olduğu bölgelerde daha fazla bildirilmeye başlanmıştır. Bebeklik döneminde laringeal infiltrasyona bağlı boğuk bir ağlama ile başlar. Zamanla deri ve mukoza değişiklikleri klinik olarak belirgin hale gelir. Etkilenen bireyler, laringeal obstrüksiyon yaşamadıkça normal bir yaşam süresine sahiptir. Bu hastaların takibi için multidisipliner bir yaklaşım önerilmektedir.

Key words: ECM1, lipoid proteinozis, moniliform blepharosis

\section{Introduction}

Lipoid proteinosis (LP) is a rare autosomal recessive genodermatosis characterized by the accumulation of an amorphous hyaline material in various regions of the body, including skin, mucous membranes, brain, internal

Corresponding author: Isa An, Dept. of Dermatology and Venereology, Sanliurfa Training and Research Hospital, Sanliurfa, Turkey Phone: +90 41431717 17, E-mail: is_an89@hotmail.com

Received: 13 May 2021 Accepted: 23 June 2021

Conflicts of Interest: None

Funding: None

How to cite this article: An I, Aksoy M, Ozturk M, Ayhan E. Mucosa 2021;4:30-40

(c) (i) (-) This work is licensed under a Creative Commons Attribution-NonCommercial 4.0 International License. 
organs. ${ }^{1}$ LP was first defined by Urbach and Wiethe with the name "Lipoidosis Cutis Et Mucosae" in 1929.2 This disease affecting both sexes equally is associated with mutations in the coding gene of extracellular matrix protein 1 (ECM1). ${ }^{3}$ During the infancy, it begins with hoarseness due to laryngeal infiltration. Gradually, skin and mucous changes become clinically evident. In face and extremities, vesicles and hemorrhagic crusts recover by leaving the atrophic scarring however it is unclear whether this is a primary or secondary phenomenon. while on the extensor surfaces, verrucous and keratotic lesions occur. ${ }^{1,4-6}$ The disease is typically slow progressing, but usually follows a benign course. Almost any organ can be affected. ${ }^{7-11}$ The affected individuals have a normal survey unless laryngeal obstruction develops. There is no precise and effective treatment of the disease. ${ }^{12,13}$

In this article, the epidemiology, pathogenesis, clinical characteristics, histopathology, diagnosis and treatment of LP will be reviewed.

\section{Epidemiology}

The incidence and prevalence of LP are not fully known. Approximately 400 cases have been reported so far in the literature..$^{1,4,8,14-17}$ In particular, it is more often seen in South Africa, in the North Cape Province, including the Namaqualand region where immigrants migrated from Germany in the mid $17^{\text {th }}$ century. ${ }^{18}$ The majority of LP patients in the literature are reported from Turkey although real prevalence is not known. . $^{1,4,8,14,19,20}$ We think that consanguineous marriage rates in eastern Turkey may have an effect on this.

\section{Pathophysiology}

LP is caused by mutations in the gene encoding the extracellular matrix protein 1 (ECM1) found on chromosome 1q21. ${ }^{21}$ The ECM1 protein plays important biological and physiological roles in the regulation of angiogenesis, epidermal differentiation, and functions of dermal collagen and proteoglycans. ECM1 also shows over-expression in certain malignancies and is abnormally expressed in chronologically aged and photo-aged skin. Its role in wound healing, scarring, and aging is speculated but not yet defined. ${ }^{3,16}$ ECM1 proteins have also been shown in liver, heart, lungs, small intestine, prostate, pancreas, testicles, ovary, placenta, kidneys, skeletal muscle. .,21,22 $^{2}$

The loss of normal function of ECMI in LP is associated with a wide variety of clinical abnormalities due to infiltration of the skin and internal organs with hyaline-like material. The eosinophilic hyaline- like material is deposited in all affected organs, however it is unclear whether this is a primary or secondary phenomenon. The details of the genotype-phenotype correlation regarding the nature of the hyaline deposits are currently under investigation. ${ }^{16}$

ECM1 has been shown to inhibit MMP-9 activity through protein-protein interaction. ${ }^{23}$ Increased MMP9 activity may contribute to hyaline changes in the dermis in LP patients. ${ }^{24}$

\section{Genetics}

LP is a rare and autosomal recessive inherited disease. ${ }^{5}$ Hamada et al., performed the first linkage analysis and survey of the ECM1 gene in patients with LP, and identified the localization of the ECM1 gene at human chromosome 1q21 locus. ${ }^{25}$ Further studies indicated the role of an ECMI gene mutation in LP. Systematic surveys across different countries and regions demonstrated variable mutation points of the ECM1 gene in individual patients with LP, suggesting the potential gene polymorphism of the ECMl gene in patients with LP. ${ }^{8,21,22,26,27}$

Afifi et al., in their study on $12 \mathrm{LP}$ patients from 10 different families in Egypt, had detected 5 new ECM1 mutations in exon 1 (c.10_1linsC), exon 6 (c.690_691delAG), exon 7 (c.734G>A), exon 8 (c.1286_1287delAA), and intron 9 (c.1393-1G>T). ${ }^{26}$ Dertlioğlu et al., in their study on 19 LP patients from 5 different families in Turkey, had detected ECM1 gene mutations in exon 6 (c.507delT, $658 \mathrm{~T}>\mathrm{G})$, exon $9(157 \mathrm{C}>\mathrm{T}, 727 \mathrm{C}>\mathrm{T})$, and exon 10 (c.93_94delGCinsTT). ${ }^{27}$

According to the The Human Gene Mutation Database 
(HGMD) 71 pathogenic mutations in ECM1 have been reported in LP patients from different geographical areas, including 32 missense/nonsense substitutions, 9 splicing substitutions, 26 small deletions/insertions (indels) and 4 gross deletions/insertions. ${ }^{28}$

Hamada et al., suggested a genotype-phenotype correlation based on the location of the mutation, with a slightly milder phenotype for patients with mutations in exon 7 compared to patients with mutations outside exon 7. The splice variant ECM1b lacks exon 7 and is therefore not affected by mutations located in this exon. ${ }^{29}$ However, Youssefian et al., noted phenotypic heterogeneity in three families with 12 LP patients, although all patients were homozygous for the mutation c.507delT in exon 6 . While existing features of LP were similar in most patients, severity and expressivity differed substantially between patients,

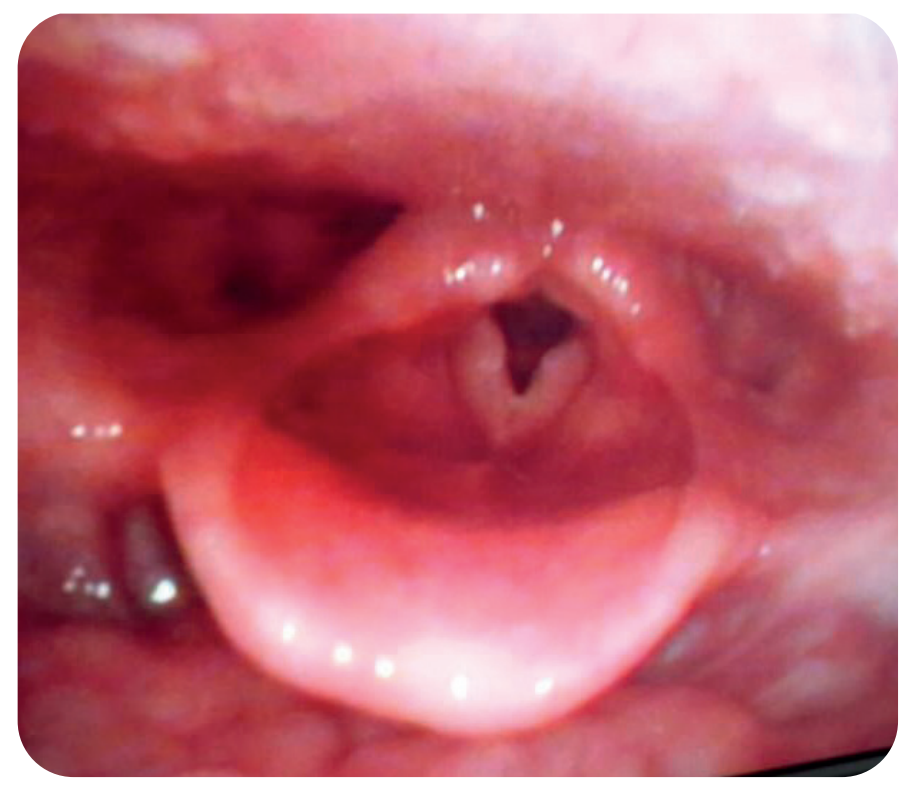

Fig. 1. Thickening of the vocal cords even between patients from the same family. ${ }^{30}$ The clinical variability between siblings diagnosed with LP carrying the same homozygous mutation indicates that genotype is not the only factor determining the phenotype. Genetic, epigenetic, and environmental factors probably play a role in the clinical expression of LP. ${ }^{3,26-28}$

\section{Clinical findings}

The earliest finding is a weak or hoarse cry that occurs early in life due to the accumulation of hyalinelike material in the vocal cords. ${ }^{20}$ (Fig. 1-2) Mucosal symptoms appear at birth or in the first few years of life. ${ }^{11}$ Cutaneous manifestations usually arise during the first two years of life. ${ }^{5}$ Neurpshychiatric symptoms of LP are more common in patients older than 10 years of age. ${ }^{15}$

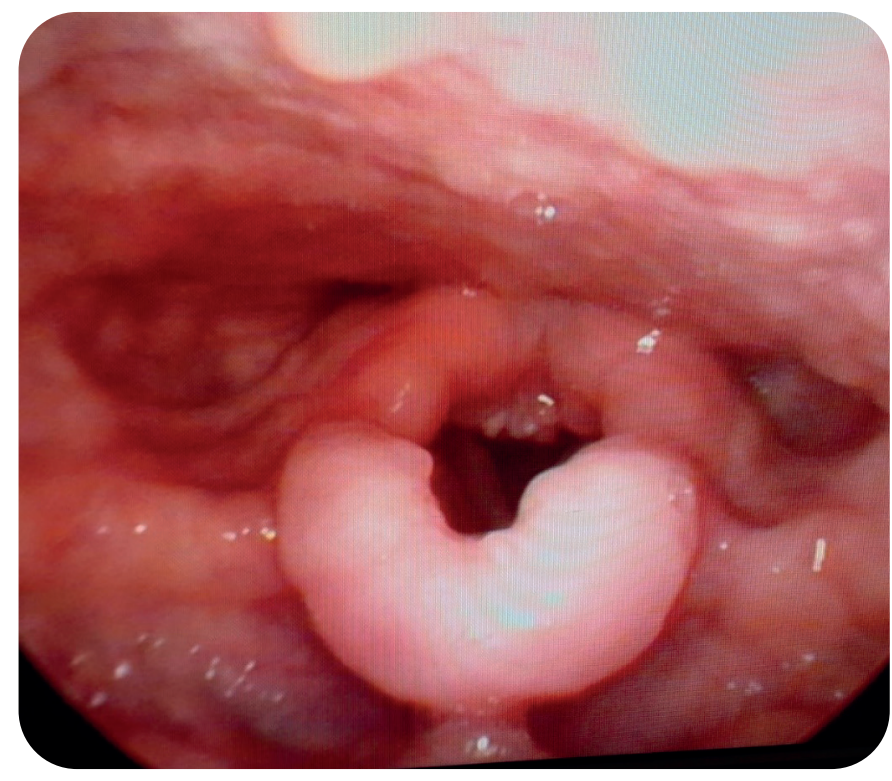

Fig. 2. Thickening of the vocal cords and hypertrophic changes in the arytenoid and interarytenoid region 


\section{Cutaneous findings}

Cutaneous findings usually begin in the early stages of the disease, usually in the first two years. Lesions such as vesicles and bullae usually begin with hemorrhagic crusts in areas of friction or trauma such as the face and extremities (Fig. 3) and heal leaving atrophic scarring (Fig. 4). ${ }^{14}$ A thickened skin is formed, which creates a waxy appearance due to dermal accumulation of amorphous hyaline substance, often on the facial skin, eyelids, axillae and scrotum. Finally,

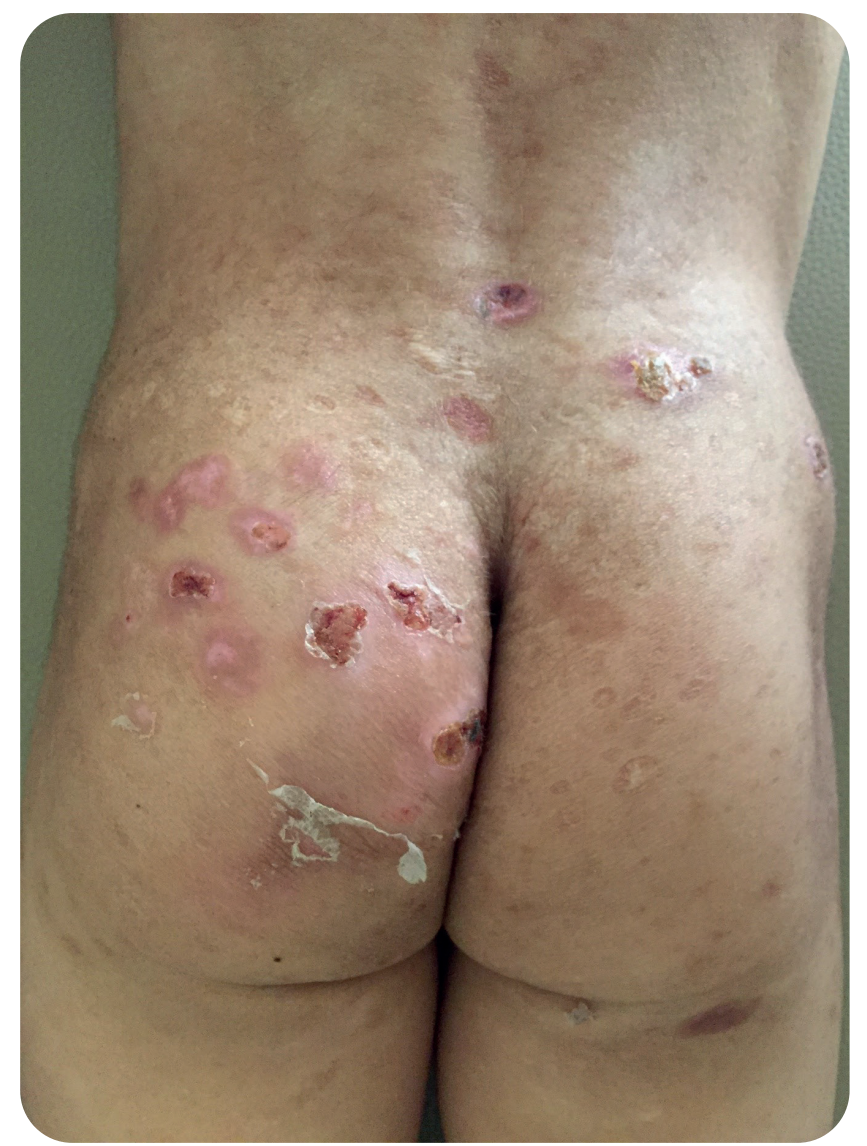

Fig. 3. Ulcerated lesions with hemorrhagic crusts and multiple atrophic scars on the back and buttocks

hyperkeratotic, verrucous papules (Fig. 5) and plaques occur on surfaces exposed to trauma such as elbows, knees and hands. ${ }^{5,6,14}$ Papules, plaques, and nodules may be found primarily on the face, but also in the

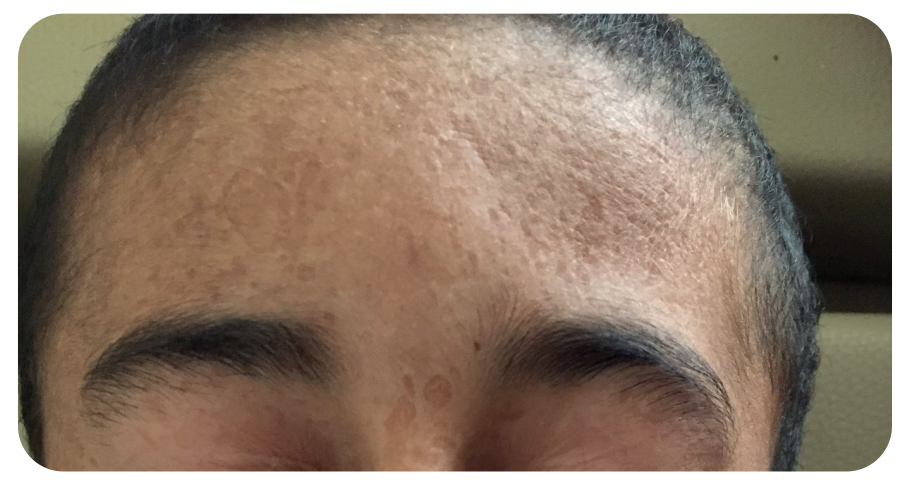

Fig. 4. Facial skin thickening and multiple atrophic scars

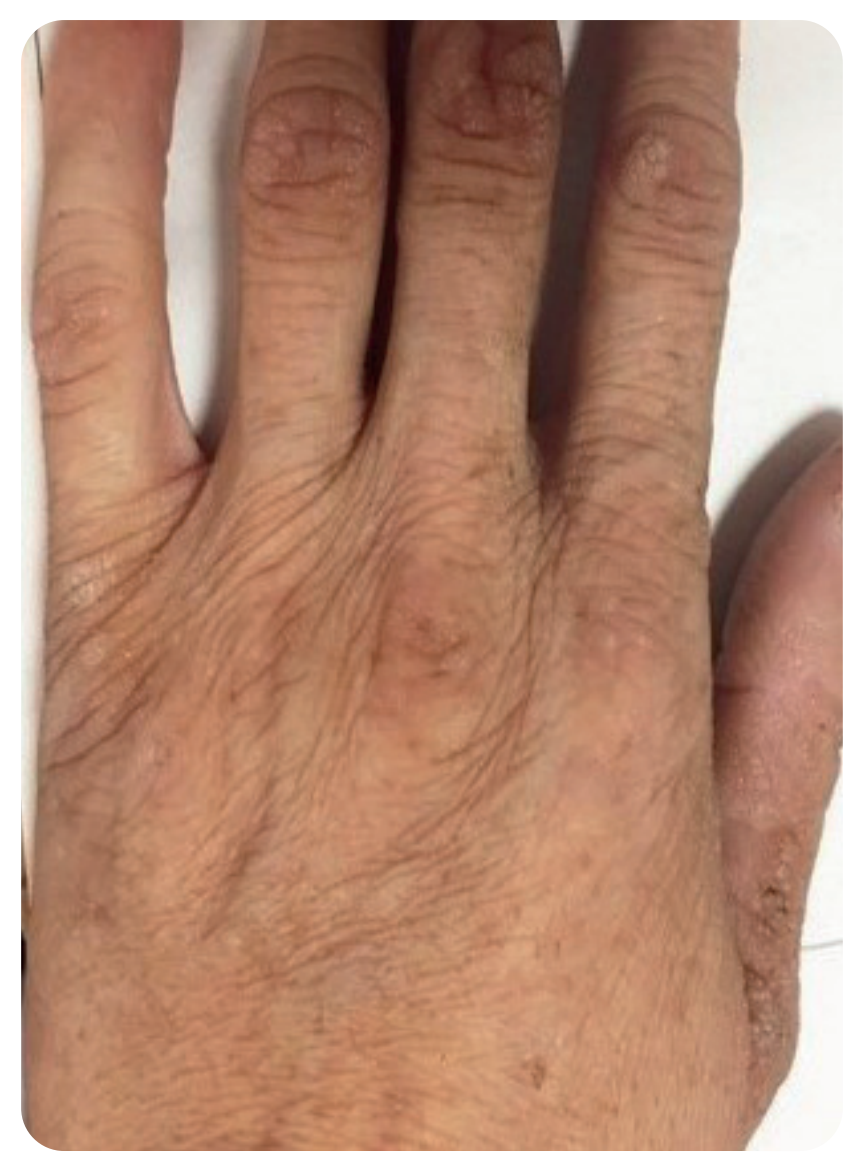

Fig. 5. Verrucous lesions on the dorsum of the hand

axilla and scrotum. Irregular or widespread alopecia may be seen due to the involvement of the scalp, but alopecia is not a finding in most cases. Nail dystrophy due to nail bed involvement may be seen in some 
cases. ${ }^{1,414,15,31}$ Nico et al., stated that the first symptom before the development of characteristic skin lesions in LP is hardening of the lip and stated that a mucosal biopsy from lip including lamina propria may be a good method for the early diagnosis of LP. ${ }^{32}$

Differential diagnosis of skin lesions includes impetigo, herpes infection, papular mucinosis, erythropoietic protoporphyria, epidermolysis bullosa, lichen amyloidosis, lepra, colloid milium, syringoma, cutaneous xanthomatosis, hydroae vacciniforme, pseudoxanthoma elasticum, incontinentia pigmenti, juvenile hyaline fibromatosis, infantile systemic hyalinosis and non-Langerhans cell histiocytoses. . $^{1,414,15,31}$

\section{Mucosal findings}

Mucosal symptoms appear at birth or in the first few years of life. Generally oral mucosa is the most severely affected area. The most commonly affected areas are labial mucosa, tongue, lingual frenulum, buccal mucosa and palate. ${ }^{11}$ Cobblestone appearance of the oral mucosa, yellow lip nodules, lipeversion, vegetative lesions, fissures in the lateral commissures and oral ulcers may be seen in patients with widespread disease. ${ }^{33,34}$ Involvement of salivary glands, usually submandibular and parotid glands, may cause hyposalivation. Recurrent parotitis (Fig. 6) and dental caries may occur as a result of deposits blocking the Stenson canal. The tongue is usually woody hard with no dorsal papillae, and the frenulum is shortened and thickened. (Fig. 7). Inadequate extension of the tongue as a result of frenulum involvement is diagnostic. Hypoplasia or aplasia may occur in the teeth, especially in the lateral incisors and premolars. ${ }^{11,32-36}$

The largest series of oral findings observed in patients with LP was analyzed by Frenkel et al. They analyzed 133 cases from 1948 to 2016 , as well as four cases of their own. In this study, tongue (68\%), floor of the mouth (55.8\%), lips (43\%) and buccal mucosa (40\%) were found to be the most frequently affected mouth regions. The palate $(25 \%)$ and gums $(6 \%)$ were the least affected areas. It was stated that the gums tended to be affected in older patients, while the palate tended to be affected in younger ones. Skin scars were reported to be significantly less in patients with palate and labial lesions. ${ }^{11}$

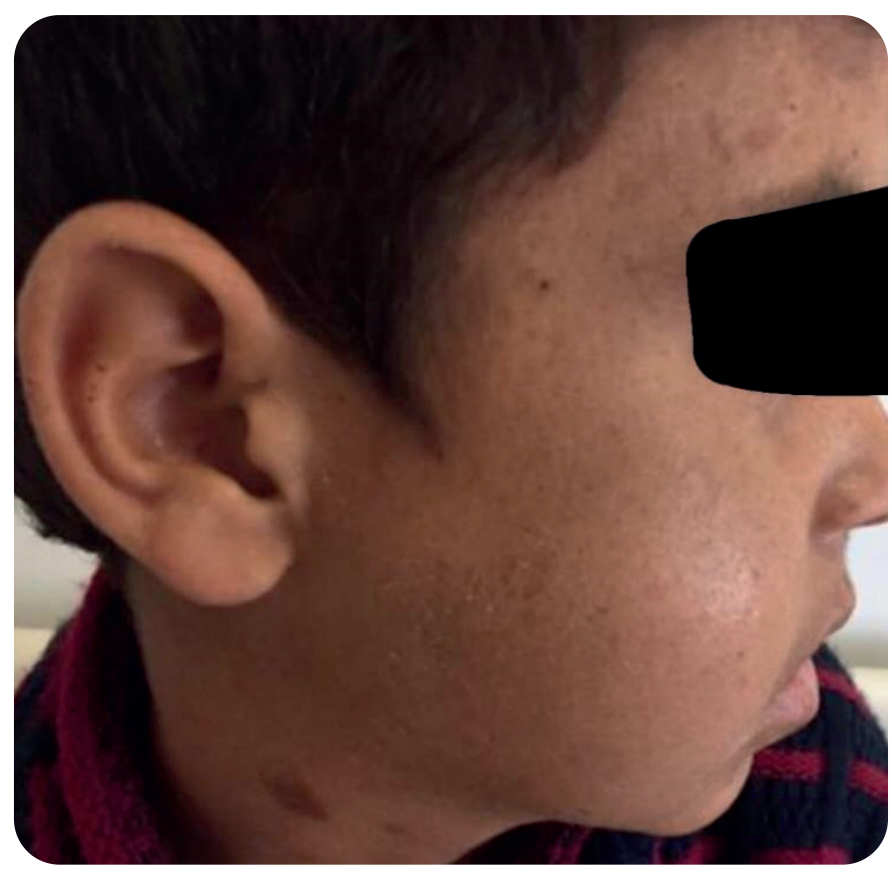

Fig. 6. Recurrent parotitis in a child with lipoid proteinosis

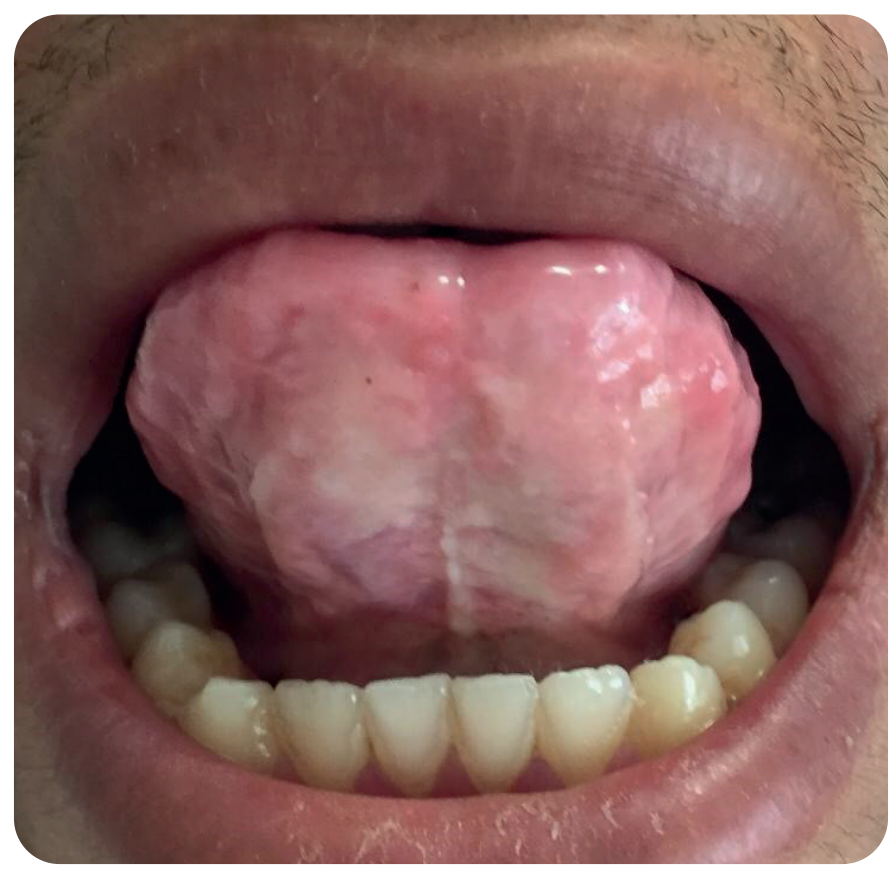

Fig. 7. Decrease in tongue movements due to involvement of the frenulum 


\section{Neuropshychiatric findings}

Bilateral, comma-shaped symmetrical calcification of the amygdala occurs in 50\% of patients with LP and is considered a pathognomonic finding. ${ }^{37,38}$ Calcification has also been reported in the hippocampus, parahippocampal gyrus, basal ganglia, uncinate gyrus, pineal gland, and perirhinal and parietal cortexes. ${ }^{39,40-43}$ The pathophysiological mechanisms and localization of calcifications are not fully understood. Central nervous system(CNS) infiltration specifically includes hippocampal capillaries, resulting in wall thickening and perivascular calcium deposition. ${ }^{10}$ Calcifications develop slowly and are therefore more common in patients older than 10 years of age and those with a longer disease duration. ${ }^{15}$ It is estimated that epilepsy occurs in approximately $25-50 \%$ of LP patients. ${ }^{38}$ In a study evaluating seven LP patients with intracranial calcifications, it was stated that four patients had epilepsy that started in childhood or young adulthood, the most common subtype was focal seizures, and patients with some mutations tended to be resistant to antiepileptic therapy. ${ }^{40}$ In a study in which 10 patients with LP were evaluated, decreased perfusion in the medial temporal lobe in three patients was found, and amygdaloid complex calcification and degeneration were found in six patients. Although these nine patients were not different from healthy controls in terms of cognitive functions, they were different from healthy controls in terms of facial expression recognition, emotional processing, and learning and recognition associated with smell. ${ }^{43}$

Neuropshychiatric symptoms of LP may include epilepsy, migraine, varying degrees of mental retardation, depression, anxiety, panic attack, memory dysfunction, abnormal social interaction patterns, dystonia, hallucination, schizophrenia, and spontaneous central nervous system hemorrhage..$^{10,37-41}$

\section{Ocular findings}

The most common and pathognomonic ocular finding of LP is linearly sequenced pearly papules on the eyelid called moniliform blepharosis. ${ }^{9,44}$
(Fig. 8) In addition to its diagnostic value, moniliform blepharosis may accompany the infiltration of the Zeiss, Moll and Meibomian glands, and consequently cause madarosis, trichiasis and sometimes distichiasis. ${ }^{44}$ Another common finding is macular focal degeneration and drusen formation in the Bruch's membrane in approximately $30-50 \%$ of patients. ${ }^{9,45}$ Uncommon ocular symptoms of LP include cataract, lens dislocation, corneal ulceration, corneal opacities, keratoconus, uveitis, glaucoma, impaired color vision, light hypersensitivity, retinitis pigmentosa, epiphora, dry eye, nasolacrimal duct obstruction, iris and pupillary disorders and temporary blindness. ${ }^{9,44-47}$

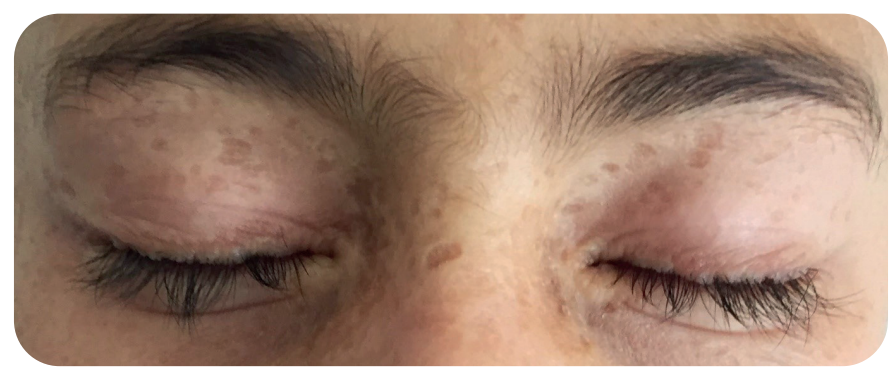

Fig. 8. Moniliform blepharosis in the eyelids

\section{Otolaryngological findings}

A weak or hoarse cry from birth or starting in early infancy is typical and remains throughout life. ${ }^{20}$ Hofer et al., found hoarseness at birth in 26 of $27 \mathrm{LP}$ patients. ${ }^{48}$ Savage et al., reported that hoarseness was present in congenital or early infancy in approximately two-thirds of LP patients. ${ }^{49}$

Although LP is very rare, airway obstruction may be life-threatening, and death due to laryngeal involvement has been reported. ${ }^{20}$ Dertlioglu et al., evaluated 10 LP patients with hoarseness and found hyaline deposits, thickened and tuberous vocal cords and decreased movement of vocal cords in indirect laryngoscopic examination of nine patients. ${ }^{1}$ On the other hand, Yukkaldiran et al., in their study with 21 LP patients, found thickening in vocal cords in all patients, hypertrophic changes in arytenoids in 13 
(61.9\%) patients, and thickening in the interarytenoid area in $10(47.6 \%)$ patients. $^{20}$

Differential diagnosis in patients with hoarseness includes vocal cord polyp and nodules, vocal cord paralysis, laryngitis, laryngeal hemangioma, laryngeal cysts and the disease may affect larynx such as laryngeal amyloidosis, congenital dysphonia, hypothyroidism, and gastroesophageal reflux disease..$^{15,20}$

In a study evaluating cochlear function and hearing in LP patients, pure tone audiometry, tympanometry and distortion product otoacoustic emission tests were performed in 20 patients and a healthy control group. It was stated that cochlear functions of patients with LP were affected by the increase in their hearing thresholds, and decreased signal-noise responses, and it was stated that LP patients were candidates for hearing loss in their later stage of life. ${ }^{8}$

\section{Gastrointestinal findings}

It has been reported that gastrointestinal system involvement is rare in LP, and hyaline material accumulation is shown in visceral biopsies taken from the esophagus, stomach, small intestine and rectum in autopsy cases. ${ }^{50,51}$ Esophageal involvement was not reported in two different studies including 14 and 10 LP patients reported from Turkey. ${ }^{1,4}$ Dysphagia has been described as a typical LP symptom in two different cases of LP. ${ }^{52,53}$ Al-Bitar et al., stated that a Saudi Arabian patient with LP had esophageal involvement, but the authors did not report the endoscopic findings of that case..$^{54}$ Lima et al., observed multiple yellowish nodules along the esophagus, stomach and duodenum in upper gastrointestinal tract endoscopy of a LP patient with epigastric pain, postprandial fullness and dyspepsia without esophageal symptoms. Esophageal manometry was found to be normal in this patient. ${ }^{7}$ Caccamo et al., described a patient with typical LP lesions in the small intestine and gastrointestinal bleeding. ${ }^{55}$ It has been reported that gastrointestinal involvement in LP is generally asymptomatic and some patients with symptoms tend to improve with age. ${ }^{7}$

\section{Histopathology}

In the Hematoxylin-Eosin stained sections of the early skin lesions of LP, pink hyaline-like thickening is observed in the capillaries in the papillary dermis. ${ }^{16}$ Rao et al., found non-acantholytic intraepidermal bullae in the histopathological examination of vesicular lesions on the skin of LP patients. ${ }^{56}$ Ko et al., on the other hand, detected extensive non-dyskeratotic acantholysis with intraepidermal blister formation in early lesions of LP and stated that this disease may be an acantholytic dermatosis. ${ }^{57}$

The old skin lesions of LP have hyperkeratosis, sometimes papillomatosis, and a thickened dermis with pink hyaline bundles in a diffuse pattern. These bundles are often arranged perpendicular to the dermoepidermal junction. The accumulation of hyaline in the lower dermis is less (Fig. 9-10). The hyaline mantle may surround the hair follicles, sebaceous glands, and rarely the errector pili muscle, as well as the eccrine glands. ${ }^{16,58}$ The lesions of $18 \mathrm{LP}$ patients with late-stage skin lesions were examined histopathologically in a study by An et al. In this study, epidermal atrophy, hyperkeratosis, pigment incontinence in the basal layer, amorphous material

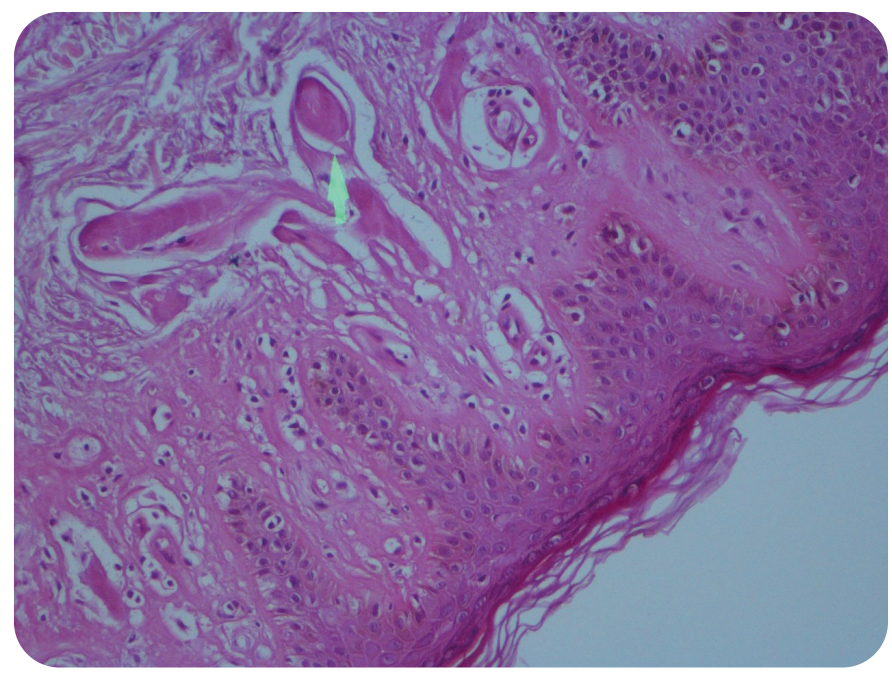

Fig. 9. Hyalinized material stained with PAS around the vessels in the papillary dermis (PASx400) 


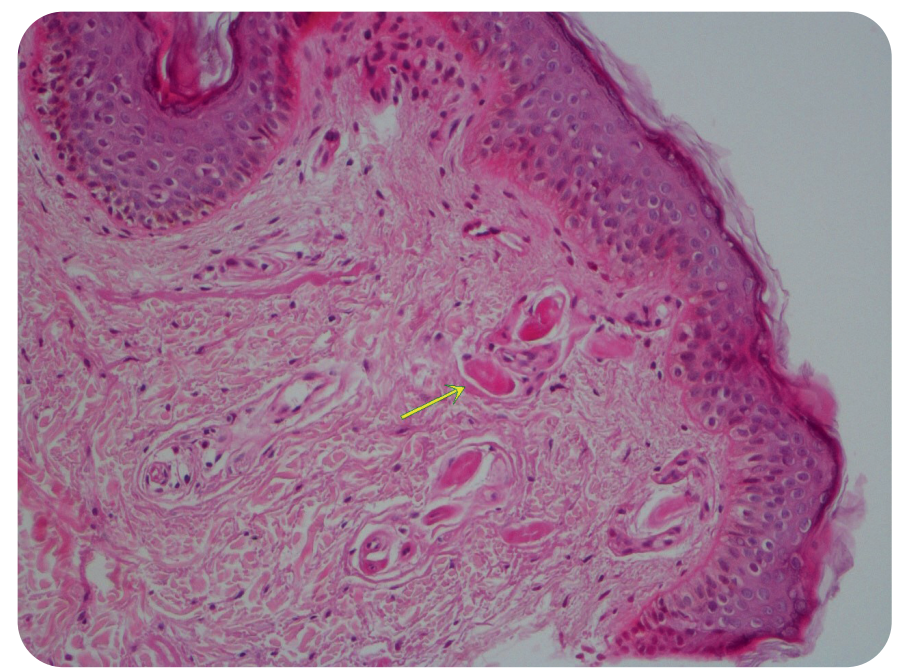

Fig. 10. Hyalinized material around the vessels in the papillary dermis (H\&Ex200)

accumulation in the dermis, inflammatory elements in the papillary dermis, fibrosis, papillomatosis, PAS positivity around the perivascular and eccrine glands, flattening and melanophage in the retes were observed in histopathological examination. ${ }^{16}$

\section{Diagnosis}

The diagnosis of LP is made by characteristic clinical findings (hoarseness, vesicular lesions in the early period, atrophic scars on the face and extremities in the late period), identification of biallelic ECM1 pathogenic variants in molecular genetic testing, and the presence of characteristic findings in histopathological examination including deposition of an eosinophilic, periodic acid-Schiff positive hyaline material in the papillary dermis and around the blood vessels. ${ }^{4,16,27,59,60,61}$

\section{Treatment}

Treatment options are very limited in LP, and although various agents have been used in the treatment, there is no effective treatment option. ${ }^{1,4,14}$

Kaya et al., reported that two years of treatment with $600 \mathrm{mg} /$ day of D-penicillamine provided both clinical and histological improvement in LP. ${ }^{62}$

Wong et al., reported that in a 41-year-old LP patient, after three years of continuous oral dimethyl sulfoxide
(DMSO) treatment, the patient's skin lesions, hoarseness, and abnormal esophageal function improved significantly. ${ }^{63}$ Ozkaya-Bayazit et al., on the other hand, stated that DMSO had no benefit for skin, mucosal lesions and hoarseness in three LP patients with an average of three years of treatment. ${ }^{64}$ It has been reported that systemic retinoids such as acitretin or etretinate may be effective in the treatment of cutaneous and laryngeal lesions by reducing the amount of hyaline-like material in the dermis. ${ }^{1,4,14,65}$ Gruber et al., showed the positive effects of $10 \mathrm{mg}$ etretinate treatment on skin lesions in two LP patients. ${ }^{66}$ Toosi et al. ${ }^{67}$ and Gunduz et al ${ }^{68}$ reported cases of LP who were treated with acitretin and resulted in improvement in voice but had no effect on skin lesions. Bakry et al., showed that acitretin was effective in both cutaneous and mucosal lesions in two LP patients. ${ }^{12}$ Acitretin treatment, which is used at a dose of $0.5 \mathrm{mg} / \mathrm{kg} / \mathrm{d}$ for up to six months in LP, has been reported to improve hoarseness, the appearance of vesiculobullous lesions and palmoplantar hyperkeratosis. ${ }^{1,67}$ Systemic steroids may be used in the treatment of oral ulcers associated with LP. ${ }^{69}$

Chemical peeling, dermabrasion and carbon dioxide laser treatment can also be used for the treatment of skin lesions. ${ }^{14}$ It has been reported that two sessions of Er: YAG (erbium-doped yttrium aluminum garnet) laser treatment performed every six weeks for facial scars of LP patients provided a good cosmetic improvement during the 2-year follow-up period. ${ }^{70}$ Madura et al., successfully treated skin lesions of a patient with LP with a combination regimen of fractional carbon dioxide and non-ablative radio frequency, and stated that this combination therapy was more effective than laser therapy alone. ${ }^{13}$

Microlaryngoscopic excision and carbon dioxide (CO) laser may be successful for patients with vocal cord involvement and phonation impairment. However, there is a risk of postoperative granulation tissue formation. Therefore, surgical intervention should only be considered in patients with risky airway involvement. ${ }^{15}$ 


\section{Conclusion}

LP is an inherited disease that can affect various parts of the body, including skin, mucous membranes, and internal organs. Although this disease is rare, it has been reported more frequently in our country, especially in regions where consanguineous marriages are common. Genetic counseling should definitely be given to these patients and their families. Depending on the symptoms of the disease, a multidisciplinary approach including dermatologist, otolaryngologist, ophthalmologist, psychiatrist, neurologist, dentist, gastroenterologist and geneticist is recommended for the follow-up of these patients.

Peer-review: Externally peer-reviewed

\section{Authorship contributions:}

Conception and design, or analysis and interpretation of data: IA, MA

Drafting the manuscript or revising the content: IA, MA, MO

Final approval of the version to be published: IA, MO, EA

\section{References}

1. Dertlioglu SB, Calik M, Cicek D. Demographic, clinical, and radiologic signs and treatment responses of lipoid proteinosis patients: a 10-case series from Sanliurfa. Int J Dermatol 2014;53:516-23.

2. Urbach E, Wiethe C. Lipoidosis cutis et mucosae. Virchows Arch A Pathol Anat Histol 1929;27:286-319.

3. Salih MA, Abu-Amero KK, Alrasheed S, et al. Molecular and neurological characterizations of three Saudi families with lipoid proteinosis. BMC Med Genet 2011;12:31.

4. Baykal C, Topkarci Z, Yazganoglu KD, et al. Lipoid proteinosis: a case series from Istanbul. Int J Dermatol 2007;46:1011-6.

5. Hegde RG, Yadav VK, Gajbhiye MI. Lipoid proteinosis: pathognomonic clinical and radiological features. BMJ Case Rep 2014;2014:bcr2014203950.

6. Vahidnezhad H, Youssefian L, Uitto J. Lipoid proteinosis. In: Adam MP, Ardinger HH, Pagon RA, et al., editors. GeneReviews ${ }^{\circledR}$ [Internet]. Seattle (WA): University of Washington, Seattle; 19932021.

7. Custodio Lima J, Nagasako CK, Montes CG, et al. Gastrointestinal involvement in lipoid proteinosis: a ten-year follow-up of a Brazilian female patient. Case Rep Med 2014;2014:952038.

8. Yukkaldiran A, An I, Erdogan O. Evaluation of cochlear involvement and hearing function in lipoid proteinosis patients. J Cosmet Dermatol 2021;20:2259-63.

9. Gunes B, Karadag R, Uzun L, et al. Is it always blepharitis? Urbach-Wiethe syndrome (lipoid proteinosis). Arq Bras Oftalmol 2019;82:242-4.

10. Balestri M, Cappelletti S, Valeriani $M$, et al. Structural focal temporal lobe seizures in a child with lipoproteinosis. Pediatr Neurol 2015;52:104-6.

11. Frenkel B, Vered M, Taicher S, et al. Lipoid proteinosis unveiled by oral mucosal lesions: a comprehensive analysis of 137 cases. Clin Oral Investig 2017;21:2245-51.

12. Bakry OA, Samaka RM, Houla NS, et al. Two Egyptian cases of lipoid proteinosis successfully treated with acitretin. J Dermatol Case Rep 2014;8:29-34.

13. Madura C, Priya A, Chandrashekar BS. Lipoid proteinosis: skin resurfacing with combination of fractional $\mathrm{CO} 2$ and non-ablative radio frequency: a rare case report. J Cutan Aesthet Surg 2018;11:91-4.

14. Dogramaci AC, Celik MM, Celik E,et al. Lipoid proteinosis in the eastern Mediterranean region of Turkey. Indian J Dermatol Venereol Leprol 2012;78:318-22.

15. LeWitt TM, Paller AS, Bell A, Zhou X. Lipoid proteinosis. In: StatPearls [Internet]. Treasure Island (FL): StatPearls Publishing; 2021 Jan.

16. An I, Guldur MA, Aksoy M, et al. Histopathological findings in patients with lipoid proteinosis. Turk J Dermatol 2019;13:99.

17. Ranjan P, Mishra D, Plesec T, et al. Familial moniliform blepharosis: clinical, histopathological and genetic correlation. Ophthalmic Genet 2015;36:160-4.

18. Van Hougenhouck-Tulleken W, Chan I, Hamada $\mathrm{T}$, et al. Clinical and molecular characterization of lipoid proteinosis in Namaqualand, South Africa. Br J Dermatol 2004;151:413-23. 
19. Oz F, Kalekoglu N, Karakullukcu B, et al. Lipoid proteinosis of the larynx. J Laryngol Otol 2002;116:736-9.

20. Yukkaldiran A, Aksoy M, Yesilova Y, et al. The frequency of laryngeal involvement in lipoid proteinosis patients. Ann Med Res 2019;26:909-12.

21. Izadi F, Mahjoubi F, Farhadi M, at al. Extracellular matrix protein 1 gene (ECM1) mutations in nine Iranian families with lipoid proteinosis. Indian J Med Res 2016;143:303-7.

22. Zhu T, Bai X, Ma D, et al. Identification of a novel three-nucleotide duplication in ECM1 in Chinese siblings affected with lipoid proteinosis. Clin Chim Acta 2021;512:122-6.

23. Fujimoto N, Terlizzi J, Aho S, et al. Extracellular matrix protein 1 inhibits the activity of matrix metalloproteinase 9 through high-affinity protein/ protein interactions. Exp Dermatol 2006;15:300-7.

24. Sung HJ, Johnson CE, Lessner SM, et al. Matrix metalloproteinase 9 facilitates collagen remodeling and angiogenesis for vascular constructs. Tissue Eng 2005;11:267-76.

25. Hamada T, McLean WH, Ramsay M, et al. Lipoid proteinosis maps to $1 \mathrm{q} 21$ and is caused by mutations in the extracellular matrix protein 1 gene (ECM1). Hum Mol Genet 2002;11:833-40.

26. Afifi HH, Amr KS, Tosson AM, et al. Lipoid proteinosis: A clinical andmolecular study in Egyptian patients. Gene 2017;628:308-14.

27. Dertlioglu SB, Edgunlu TG, Sen DE, et al. Extracellular matrix protein 1 gene mutation in Turkish patients with lipoid proteinosis. Indian J Dermatol 2019;64:436-40.

28. The Human Gene Mutation Database. Available at: http://www.hgmd.cf.ac.uk (last accessed 25 April 2021).

29. Hamada T, Wessagowit V, South AP, et al. Extracellular matrix protein 1 gene (ECM1) mutations in lipoid proteinosis and genotypephenotype correlation. J Invest Dermatol 2003;120:345-50.

30. Youssefian L, Vahidnezhad H, Daneshpazhooh M, et al. Lipoid proteinosis: phenotypic heterogeneity in Iranian families with c.507delT mutation in ECM1. Exp Dermatol 2015;24:220-2.

31. Zaouak A, Zribi H, Eleuch D, et al. Vesiculobullous eruption revealing lipoid proteinosis: a potential diagnostic pitfall. A case report and a brief review. Int J Pediatr Adolesc Med 2015;2:157-60.
32. Nico MM, Hammerschmidt M, Lourenco SV. Oral mucosal manifestations in some genodermatoses: correlation with cutaneous lesions. Eur J Dermatol 2013;23:581-91.

33. Ravi Prakash SM, Verma S, Sumalatha MN, et al. Oral manifestations of lipoid proteinosis: a case report and literature review. Saudi Dent J 2013;25:91-4.

34. Epple A, Hoxha E, Schneiderbauer R, et al. Hyalinosis cutis et mucosae: a clinical investigation with special regard to mucosal changes. J Dtsch Dermatol Ges 2018;16:211-3.

35. Lee KC, Peters SM, Ko YCK, et al. Oral manifestations of lipoid proteinosis in a 10-yearold female: a case report and literature update. Oral Surg Oral Med Oral Pathol Oral Radiol 2018;126:228-32.

36. Lourenco AG, Araujo VC, Passador-Santos F, et al. Lipoid proteinosis: a rare disease in pediatric dentistry. Braz Dent J 2020;31:186-9.

37. Meletti S, Cantalupo G, Santoro F, et al. Temporal lobe epilepsy and emotion recognition without amygdala: a case study of Urbach-Wiethe disease and review of the literature. Epileptic Disord 2014;16:518-27.

38. Agredano PM, Del Barrio CM, Martinez MC, et al. Intracranial calcifications associated with epilepsy: a case report of lipoid proteinosis. Seizure 2020;83:172-4.

39. Chandrasekaran S, Nanjundan M, Natarajan S, et al. Radiologic presentation of lipoid proteinosis with symmetrical medial temporal lobe calcifications. Radiol Case Rep 2016;10:1121.

40. Oguz AE, Dincsoy BF, Baykal C, et al. The characteristics and long-term course of epilepsy in lipoid proteinosis: a spectrum from mild to severe seizures in relation to ECM1 mutations. Clin EEG Neurosci 2018;49:192-6.

41. de Rezende Pinto WB, de Souza PV, Pedroso JL, et al. Urbach-Wiethe disease presenting with partial seizures, skin lesions and typical neuroimaging features. Clin Neurol Neurosurg 2014;126:169-70.

42. Appenzeller S, Chaloult E, Velho P, et al. Amygdalae calcifications associated with disease duration in lipoid proteinosis. J Neuroimaging 2006;16:154-6.

43. Siebert M, Markowitsch HJ, Bartel P. Amygdala, affect and cognition: evidence from 10 patients with Urbach-Wiethe disease. Brain 2003;126:2627-37.

44. Kamath SJ, Marthala H, Manapragada B. Ocular 
manifestations in lipoid proteinosis: a rare clinical entity. Indian J Ophthalmol 2015;63:793-5.

45. Abtahi SM, Kianersi F, Abtahi MA, et al. Urbachwiethe syndrome and the ophthalmologist: review of the literature and introduction of the first instance of bilateral uveitis. Case Rep Med 2012;2012:281516.

46. Mandal S, Dutta P, Venkatesh P, et al. Bilateral lens subluxation in a case of lipoid proteinosis. J Cataract Refract Surg 2007;33:1469-70.

47. Acar U, Yildiz EH, Yuksel D, Ustun H, Unlu N. Keratoconus in a case of lipoid proteinosis. Eye Contact Lens 2013;39:e25-7.

48. Hofer PA, Ohman J. Laryngeal lesions in UrbachWiethe disease (lipoglycoproteinosis; lipoid proteinosis; hyalinosis cutis et mucosae). A histopathological and clinical study, including direct laryngoscopical examinations. Acta Pathol Microbiol Scand A 1974;82:547-58.

49. Savage MM, Crockett DM, McCabe BF. Lipoid proteinosis of larynx: a cause of voice change in the infant and young child. Int J Pediatr Otorhinolaryngol 1988;15:33-8.

50. Black MM. Lipoid proteinosis, metabolic and nutritional disorders. In: Champion RH, Burton JL, Burns DA, Breathnach SM, editors. Rook/ Wilkison/Ebling textbook of dermatology. $6^{\text {th }} \mathrm{ed}$. Oxford: Blackwell Science; 1998. pp. 2460-2.

51. Caplan RM. Visceral involvement in lipoid proteinosis. Arch Dermatol 1967;95:149-55.

52. Ajdarkosh H, Shirzad S, Taher M,et al. Lipoid proteinosis: a case report Urbach \& Wiethe disease. Govaresh 2011;16:200-3.

53. Malekzad F, Rahimi H, Lotfi S, et al. Lipoid proteinosis in two Iranian sisters: a case report and review of literature. Iran Red Crescent Med J 2011;13:280-2.

54. Al-Bitar Y, Samdani AJ. Lipoid proteinosis in two brothers with multiple organ involvement from Saudi Arabia. Int J Dermatol 2004;43:360-1.

55. Caccamo D, Jaen A, Telenta M, et al. Lipoid proteinosis of the small bowel. Arch Pathol Lab Med 1994;118:572-4.

56. Rao R, Prabhu SS, Sripathi H, Gupta S. Vesiculobullous lesions in lipoid proteinosis: a case report. Dermatol Online J 2008;14:16.

57. Ko C, Barr RJ. Vesicular lesions in a patient with lipoid proteinosis: a probable acantholytic dermatosis. Am J Dermatopathol 2003;25:335-7.
58. Touart DM, Sau P. Cutaneous deposition diseases. Part I. J Am Acad Dermatol 1998;39:149-71.

59. Celik H, Aksoy M, An I, et al. The investigation of oxidative stress parameters in patients with lipoid proteinosis. J Harran Univ Med Fac 2019;16:1-7.

60. Aksoy M, An I. Evaluation of inflammatory parameters in lipoid proteinosis patients. Dermatol Ther 2020;33:14495.

61. Vural C, Gonul II, Dursun A. Laryngeal lipoid proteinosis (Urbach-Wiethe's disease): a case report. Turk Patoloji Dergisi 2009;25:45-8.

62. Kaya TI, Kokturk A, Tursen U, Ikizoglu G, Polat A. D-penicillamine treatment for lipoid proteinosis. Pediatr Dermatol 2002;19:359-62.

63. Wong CK, Lin CS. Remarkable response of lipoid proteinosis to oral dimethyl sulphoxide. $\mathrm{Br} \mathrm{J}$ Dermatol 1988;119:541-4.

64. Ozkaya BE, Ozarmagan G, Baykal C, Ulug T. Oral DMSO therapy in 3 patients with lipoidproteinosis. Results of long-term therapy. Hautarzt 1997;48:477-81.

65. Carnevale C, Castiglia D, Diociaiuti A, et al. Lipoid proteinosis: a previously unrecognized mutation and therapeutic response to acitretin. Acta Derm Venereol 2017;97:1249-51.

66. Gruber F, Manestar D, Stasic A, et al. Treatment of lipoid proteinosis with etretinate. Acta Derm Venereol 1996;76:154-5.

67. Akoglu G, Karaduman A, Ergin S, et al. Clinical and histopathological response to acitretin therapy in lipoid proteinosis. J Dermatolog Treat 2011;22:178-83.

68. Gunduz O, Sahiner N, Atasoy P, et al. Acitretin treatment for lipoid proteinosis. Case Rep Dermatol Med 2012;2012:324506.

69. Kutlu O, Eksioglu HM. The role of systemic steroids in oral ulcers associated with lipoid proteinosis. Dermatol Ther 2021;34:e14582.

70. Caliskan E, Acikgoz G, Tunca M, et al. Treatment of lipoid proteinosis with ablative Er:YAG laser resurfacing. Dermatol Ther 2015;13:291-5. 